Bruce D. Butler PH D, Basil C. Leiman мB в CH, Jeffrey Katz $\mathrm{MB}$ СH B

\title{
Arterial air embolism of venous origin in dogs: effect of nitrous oxide in combination with halothane and pentobarbitone
}

The effects of using nitrous oxide $\left(\mathrm{N}_{2} \mathrm{O}\right)$ with halorhane or pentobarbitone anaesthesio on the filtration of venous air emboli (VAE) by the pulmonary circulation were studied in dogs. Dogs anaesthetized with either pentobarbitone, pentobarbitone $/ \mathrm{N}_{2} \mathrm{O}$, halothune, of halothane $\mathrm{N}_{2} \mathrm{O}$ werce embolized with venous air into the right atrium at 0.25 to $0.35 \mathrm{ml} \cdot \mathrm{kg}^{-1} \cdot \mathrm{min}^{-1}$ for $30 \mathrm{~min}$. The animals were in a supine, head down position. A Doppler ultrasonic probe located over the suprarenal aorta detected arterial bubbles that escaped filtration by the lungs. No bubbles were detected at $0.25 \mathrm{ml} \cdot \mathrm{kg}^{-1} \cdot \mathrm{min}^{-1}$, but at $0.30 \mathrm{ml} \cdot \mathrm{kg}^{-1} \cdot \mathrm{min}^{-1}$ the incidence was 11 per cent (pentobarbitone), O per cent (pentobarbitone $\mathrm{N}_{2} \mathrm{O}$ ), 33 per cent (halothane), and 63 per cent (halothane/ $\mathrm{N}_{2} \mathrm{O}$ ) and at $0.35 \mathrm{ml} \cdot \mathrm{kg}^{-1} \cdot \mathrm{min}^{-1}, 44 \mathrm{per}$ cent (pentobarbitone), 14 per cent (pentobarbitone $\mathrm{N}_{2} \mathrm{O}$ ), and 56 per cent (halothane). Half of the dogs receiving VAE with halo. thane $/ \mathrm{N}_{2} \mathrm{O}$ at $0.30 \mathrm{ml} \cdot \mathrm{kg}^{-1} \cdot \mathrm{min}^{-1}$ died within the first $10 \mathrm{~min}$ of the air infusion. Thus, no animals were studied at the next higher dose $\left(0.35 \mathrm{mi} \cdot \mathrm{kg}^{-1} \cdot \mathrm{min}^{-1}\right)$. The results suggest that the occur. rence of VAE with nitrous oxide anaesthesin may result in greater haemodynamic consequence and increased likelihood for spillover of the venous bubbles into the arteries if used with halothane as compared to pentobarbitone.

\section{Key words}

COMPLICATIONS: venous air embolism, air embolism; ANAESTHETICS, INHALATION: halOthane; ANAESTHETICS, GASES: nitrous oxide; HYPNOTICS, BARBITURATES: pentobarbitone.

From the Department of Anesthesialogy, The University of Texas Medical School, Houston, Texas.

This work was supported in part by BRS Grant \#RR-05745-11 U.S. Public Health Service.

Address correspondence to: Dr. Bruce D. Butler, Department of Anesthesiology, The University of Texas Medical School, 6431 Fannin, MSMB 5.020, Houston, Texas 77030.
Venous air embolism has been reported in a variety of surgical procedures with varying incidence. ${ }^{1}$ As the air bubbles are carried to the lungs, there is an associated cardio-pulmonary response including pulmonary hypertension, elevated right atrial and right ventricular pressure, acid/base disturbances, and pulmonary oedema. ${ }^{2.3}$ These symptoms can be more pronounced when nitrous oxide $\left(\mathrm{N}_{2} \mathrm{O}\right)$ is used as part of the anaesthetic techrique. Because nitrous oxide is $34-35$ times more soluble in blood than nitrogen, it causes an increase in bubble volume, thus increasing the volume of gas that ultimately reaches the pulmonary circulation. ${ }^{4}$

As the target organ for venous emboli, the lungs are also considered an effective organ of excretion and therefore a filter for preventing the "spillover" of bubbles into the systemic circulation." With the likelihood of spillover, there is an increased risk for coronary or cerebral air embolism. We have shown in carlier studies that venous gas bubbles spillover into the arteries ${ }^{0,7}$ with excessive rates of air infusion and that the incidence may depend upon the anaesthetic technique ${ }^{8}$ These conditions are reported in dogs in the absence of atrial septal communications and similar incidents have been described in several case reports ${ }^{9-11}$ where cerebral air embolism occurred following venous air embolism.

The purpose of this study was to examine the pulmonary filtration of venous air infusions in dogs anaesthetized with pentobarbitone $/ \mathrm{N}_{2} \mathrm{O}$ or halothane $/ \mathrm{N}_{2} \mathrm{O}$. Comparisons are made with dogs anaesthetized with either pentobarbitone or halothane alone. Venous air bubbles that escaped filtration by the lungs and spilled over into the arterial circulation were detected by arterial Doppler ultrasound.

\section{Methods}

Anaesthesia was induced in one group of dogs with pentobarbitone sodium ( $30 \mathrm{mg} \cdot \mathrm{kg}^{-1}$, IV) and maintained with $5 \mathrm{mg} \cdot \mathrm{hr}^{-1}$. The animals were intubated and venti- 
lated with a fixed volume ventilator (Harvard) with oxygen ( 30 per cent) and nitrous oxide ( 70 per cent) at a rate and tidal volume to maintain arterial $\mathrm{PCO}_{2}$ at $35-40 \mathrm{mmHg}$. In a second group of dogs, anaesthesia was induced with thiopentone (25 mg $\mathrm{kg}^{-1}$, IV) and the animals were intubated and ventilated with oxygen ( 30 per cent), in nitrous oxide ( 70 per cent). Anaesthesia was maintained in the second group of dogs with inspired halothane (1-1.5 per cent). Inspired oxygen tensions were measured with an in-line oxygen analyzer (IL 401) and halothane delivery controlled with a Fluotec vaporizer calibrated with a mass spectrometer (Perkin-Elmer). The dogs anaesthetized with pentobarbitone $/ \mathrm{N}_{2} \mathrm{O}$ (Group 1) were divided into three subgroups depending on the volume of venous air. The dogs anaesthetized with halothane $/ \mathrm{N}_{2} \mathrm{O}$ (Group 2) were divided into two subgroups of eight animals each and received 0.25 or $0.30 \mathrm{ml} \cdot \mathrm{kg}^{-1} \cdot \mathrm{min}^{-1}$ of venous air, The Doppler data from dogs not receiving $\mathrm{N}_{2} \mathrm{O}$ had been previously determined in our laboratory. ${ }^{6.8} \mathrm{~A} 0.35 \mathrm{ml} \cdot \mathrm{kg}^{-1} \cdot \mathrm{min}^{-1}$ (halothane/ $\mathrm{N}_{2} \mathrm{O}$ ) group was not attempted as the mortality rate for the next lower group $\left(0.30 \mathrm{ml} \cdot \mathrm{kg}^{-1} \cdot \mathrm{min}^{-1}\right)$ was already 50 per cent.

Pressure monitoring catheters were placed in the abdominal aorta via the femoral artery for blood pressure (BP), left ventricle via the right carotid artery for left ventricular end-diastolic pressure (LVEDP) and the pulmonary artery via the jugular vein (PAP). The catheters were connected to strain gauge transducers (Statham P23Id) which were zero referenced at the right atrial level and calibrated with a mercury column. Cardiac output (CO) was measurcd in triplicatc using thermodilution (Instrumentation Laboratories) and electrocardiograms (ECG) were recorded from lead II. Pulmonary vascular resistance (PVR) was calculated by (PAP-LVEDP)/CO. Thirty minutes were allowed for stabilization before control data were obtained. The animals were placed in a supine head down position.

A $10 \mathrm{mHz}$ Doppler probe (Parks 912) was positioned directly over the suprarenal aorta via an abdominal midline incision for detection of venous bubbles that crossed the pulmonary circulation. The probe was held in place with a bar clamp suspended independent of the dog to avoid any artefactual signals due to gross movements. The ultrasonic signals reflected by gas bubbles were filtered and amplified for simultaneous analogue record. ing and audio interpretation.

The dogs received ait infusions into the right atrium for $30 \mathrm{~min}$ via the proximal lumen of the pulmonary artery catheter. Infusion rates were controlled with a reciprocating servo pump (Harvard). The infusion rates ranged from 0.25 to $0.35 \mathrm{ml} \cdot \mathrm{kg}^{-1} \cdot \mathrm{min}^{-1}$. Each dog received only one air infusion and recovery was monitored for $60 \mathrm{~min}$ following infusion. The size of the gas bubbles infused were approximately 500 microns in diameter as determined by terminal rise velocity measurements. This technique ${ }^{12}$ enables the determination of bubble size from the rate of rise in a static fluid column using Stoke's relation.

In those animals demonstrating arterial gas bubbles, a left thoractomy was performed between the fifth and sixth ribs to directly observe the coronary vessels for bubbles. The pericardial sac was resected and the myocardium examined in situ. This was performed at the end of the 30 min air infusion period. At the end of the $60 \mathrm{~min}$ recovery period, the animals were killed with intravenous $\mathrm{KCl}$ and the heart examined for the presence of septal defects. Those animals demonstrating scptal defects were excluded from the study.

The data were analyzed using two-way ANOVA with the Bonferroni method of multiple comparison ( $p<0.05$, significant). Fisher's Exact tests were performed on the Doppler data to determine significance between air dose and incidence and anaesthetic agent and incidence.

\section{Results}

The results of the Doppler studies are shown in Table I. There was a difference in the actual number of dogs demonstrating spillover of VAE between animals receiving pentobarbitone only (44 per cent) and those receiving pentobarbitone $/ \mathrm{N}_{2} \mathrm{O}$ (14 per cent) at $0.35 \mathrm{ml} \cdot \mathrm{kg}^{-1} \cdot \mathrm{min}^{-1}$ although this was not statistically significant. The difference in incidence in the halothane versus halothane $/ \mathrm{N}_{2} \mathrm{O}$ dogs at $0.30 \mathrm{ml} \cdot \mathrm{kg}^{-1} \cdot \mathrm{min}^{-1}$ was also not significant, although the actual cases $(3 / 9,33$ per cent versus $5 / 8,63$ per cent) were greater for the animals receiving $\mathrm{N}_{2} \mathrm{O}$ and the haemodynamic changes were greater (Tables II and III). The greatest difference in incidence of arterial air emboli was between the pentobarbitone $/ \mathrm{N}_{2} \mathrm{O}$ and halothane $/ \mathrm{N}_{2} \mathrm{O}$ groups at $0.30 \mathrm{ml} \cdot \mathrm{kg}^{-1} \cdot \mathrm{min}^{-1}(0 / 8$ versus $5 / 8, \mathrm{p}<0.05)$. Further differences were observed when comparing halothane at $0.25 \mathrm{ml} \cdot \mathrm{kg}^{-1} \cdot \mathrm{min}^{-1}$ to $0.35 \mathrm{ml} \cdot \mathrm{kg}^{-1} \cdot \mathrm{min}^{-1}$ and with halothane $/ \mathrm{N}_{2} \mathrm{O}$ at $0.25 \mathrm{ml} \cdot \mathrm{kg}^{-1} \cdot \mathrm{min}^{-1}$ to $0.30 \mathrm{ml} \cdot \mathrm{kg}^{-1} \cdot \mathrm{min}^{-1}$.

Bubbles were observed in the coronary arteries in 50 per cent (4/8) of the dogs from the 0.30 halothane $/ \mathrm{N}_{2} \mathrm{O}$ group and the same number of animals died before completion of the $60 \mathrm{~min}$ recovery period. Detection of the arterial bubbles occurred at $4-10(6.4 \pm 1.0)$ min after the venous air infusions had begun.

Blood pressure, cardiac output and left ventricular end-diastolic pressures were unchanged for the animals receiving nitrous oxide and VAE (Table II). Increases in pulmonary artery pressure were greater than two-fold ( $\mathrm{p}$ $<0.05$ ) following the venous air infusions (Table Ill) and pulmonary vascular resistances increased by greatcr than 
TABLE I Incidence of arterial air bubbles following venous air infusion

\begin{tabular}{|c|c|c|c|c|}
\hline \multirow{2}{*}{$\begin{array}{l}\text { Air dose } \\
\mathrm{ml} \cdot \mathrm{kg}^{-1} \cdot \mathrm{min}^{-1}\end{array}$} & \multicolumn{3}{|c|}{ Number of arterial bubbles/Namber of embolizations } & \multirow{2}{*}{$\begin{array}{l}\text { Halothane/ } N_{2} O \\
\text { (percentoge) }\end{array}$} \\
\hline & Pentobarbitone & Pentobarbitone $\mathrm{N}_{2} \mathrm{O}$ & Halothane & \\
\hline 0.25 & $0 / 9(0 \%)$ & $0 / 4(0 \%)$ & $0.9(0 \%) \dagger$ & $0 / 8(0 \%) \neq$ \\
\hline 0.30 & $1 / 9(11 \%)$ & WB $(0 \%)^{*}$ & $3 / 9(33 \%)$ & $5 / 8(63 \%) \ddagger$ \\
\hline 0.35 & $4 / 9(44 \%)$ & $1 / 7(14 \%)$ & $5 / 9(56 \%) \dagger$ & \\
\hline
\end{tabular}

$*_{\mathrm{p}}<0.05$, comparing pentobarbitone $/ \mathrm{N}_{2} \mathrm{O}$ to halothane $/ \mathrm{N}_{2} \mathrm{O}$ at $0.30 \mathrm{ml} \cdot \mathrm{kg}^{-1} \cdot \mathrm{min}^{-1}$

$t_{\mathrm{p}}<0.04$, comparing halothane at $0.25 \mathrm{ml} \cdot \mathrm{kg}^{-1} \cdot \mathrm{min}^{-1}$ to $0.35 \mathrm{ml} \cdot \mathrm{kg}^{-1} \cdot \mathrm{min}^{-1}$.

Ip $<0.04$, comparing halothane $\mathrm{N}_{2} \mathrm{O}$ at $0.25 \mathrm{ml} \cdot \mathrm{kg}^{-1} \cdot \mathrm{min}^{-1}$ to $0.30 \mathrm{ml} \cdot \mathrm{kg}^{-1} \cdot \mathrm{min}^{-1}$.

three-fold $(\mathrm{p}<0.05)$. Both PAP and PVR returned to baseline following the $60 \mathrm{~min}$ recovery period. Betwcengroup comparisons of PAP and PVR for dogs anaesthetized with either pentobarbitone $/ \mathrm{N}_{2} \mathrm{O}$ or halothane $/ \mathrm{N}_{2} \mathrm{O}$ were not significant.

\section{Discussion}

The consequences of venous air embolism have been linked to the site and rate of entry of air into the circulation. ${ }^{13}$ Another factor associated with increased morbidity and mortality and VAE is the use of nitrous oxide anaesthesia. ${ }^{4}$ Nitrous oxide is 34-35 times more saluble in blood than nitrogen ( 0.46 and 0.013 blood gas partition coefficients, respectively). ${ }^{4}$ Therefore, VAE expand as the gas molecules are exchanged between the blood and bubbles. ${ }^{15}$ The volume of a bubble will increase geometrically in relation to the partial pressure of ritrous oxide in the surrounding blood in a time-limited fashion. These factors have caused concem regarding the use of nitrous oxide for those patients at high risk (e.g., seated neurosurgery) for VAE.

Typically, the concem for VAE with nitrous oxide anaesthesia centres around the resultant pulmonary hypertension and decrease in systemic blood pressure. These events may be less hazardous, however, than when the venous bubbles spillover the pulmonary circulation and potentiate the risk of coronary or cercbral air embolism. The more common route by which venous bubbles enter the arteries is via a patent foramen ovale. ${ }^{16}$ In these situations, the increase in right heart pressures following VAE open the interatrial conncction and shunt bubbles directly into the left atrium. The volume of air required to cause death in dogs resulting from VAE has been reported to be as high as one litre. ${ }^{17}$ In contrast, only $2-3 \mathrm{ml}$ of air in the cerebral circulation can be fatal in man. ${ }^{18}$ Because of its ability to expand intravascular bubble size, nitrous oxide may cause complications at even lower doses of VAE.

In this study, we have examined the incidence of spillover of VAE into the arteries of dogs without cardiac septal defects. The Doppler data (Table I) indicates the spillover of venous bubbles occurs at a greater incidence (63 per cent) at $0.30 \mathrm{ml} \cdot \mathrm{kg}^{-1} \cdot \mathrm{min}^{-1}$ in dogs anaesthetized with halothane $/ \mathrm{N}_{2} \mathrm{O}$ versus pentobarbitone $/ \mathrm{N}_{2} \mathrm{O}(0$ per cent). Increased incidence in spillover of VAE also occurred with increased air doses in animals anaesthetized with halothane or halothane $/ \mathrm{N}_{2} \mathrm{O}$.

The pulmonary haemodynamic responses (Table III) were typical for that of VAE as previously reported ${ }^{3,5,6,13}$ with the peak response for PAP and PVR occurring within

TABLE II Cardiovascular data*. Mean \pm SD

\begin{tabular}{|c|c|c|c|c|c|c|c|c|c|c|}
\hline \multirow{2}{*}{$\begin{array}{l}\text { Air dose } \\
\mathrm{ml} \cdot \mathrm{kg}^{-1} \cdot \mathrm{min}^{-1}\end{array}$} & \multirow[b]{2}{*}{$n$} & \multicolumn{3}{|c|}{$B P\left(m m H_{g}\right)$} & \multicolumn{3}{|c|}{$\operatorname{CO}\left(L \cdot \min ^{-1}\right)$} & \multicolumn{3}{|c|}{ LVEDP $(\mathrm{mmHg})$} \\
\hline & & Control & Air & Recovery & Control & Air & Recovery & Control & Air & Recovery \\
\hline \multicolumn{11}{|c|}{ Pentobarbitone/nitrous oxide } \\
\hline 0.25 & 4 & $144=20$ & $130 \pm 29$ & $141 \pm 19$ & $2.7=0.6$ & $2.5 \pm 0.6$ & $2.5 \pm 0.7$ & $5.1 \pm 0.8$ & $5.9 \pm 1.6$ & $6.1 \pm 1.7$ \\
\hline 0.30 & 8 & $147 \pm 23$ & $136 \pm 23$ & $142 \pm 25$ & $3.3 \pm 1.2$ & $3.1 \pm 0.7$ & $2.6 \pm 0.8$ & $4.9 \pm 1.7$ & $5.2 \pm 2.1$ & $5.1 \pm 1.8$ \\
\hline 0.35 & 7 & $139 \pm 17$ & $139 \pm 17$ & $139=11$ & $3.3 \pm 1.1$ & $3.4 \pm 0.9$ & $3.1 \pm 1.3$ & $4.7 \pm 1.5$ & $4.8 \pm 0.9$ & $4.6 \pm 1.2$ \\
\hline \multicolumn{11}{|c|}{ Halothane/nitrous oxide } \\
\hline 0.25 & 8 & $99 \pm 17$ & $82 \pm 16$ & $90=7$ & $2.0 \pm 0.5$ & $2.3 \pm 0.4$ & $2.0 \pm 0.4$ & $6.3 \pm 0.7$ & $5.7 \pm 0.3$ & $5.5 \pm 0.4$ \\
\hline 0.30 & $\mathbf{B}$ & $99 \pm 20$ & $B 1 \pm 30$ & $90 \pm 21$ & $2.0 \pm 0.9$ & $2.2 \pm 0.8$ & $2.0 \pm 0.4$ & $5.6 \pm 0.8$ & $4.7 \pm 0.9$ & $5.4 \pm 1.3$ \\
\hline
\end{tabular}

$\mathrm{BP}=$ arterial blood pressure, $\mathrm{CO}=$ carciac output, $\mathrm{LVEDP}=$ left ventricular end-diastolic pressure

$p=$ NS.

* Data presented from surviving animals only. 
TABLE III Pulmonary haemodynamic data $\dagger$. Mean \pm SD

\begin{tabular}{|c|c|c|c|c|c|c|c|}
\hline \multirow{2}{*}{$\begin{array}{l}\text { Air dose } \\
\mathrm{ml}^{\prime} \cdot \mathrm{kg}^{-1} \cdot \mathrm{min}^{-1}\end{array}$} & \multirow{2}{*}{$n$} & \multicolumn{3}{|c|}{ PAP (mmHg) } & \multicolumn{3}{|c|}{ PVR (dynes sec $\left.\cdot \mathrm{cm}^{-5}\right)$} \\
\hline & & Contral & Air & Recovery & Cunfrol & Air & Recovery \\
\hline \multicolumn{8}{|c|}{ Penrobarbilone/mitrous oxide } \\
\hline 0.25 & 4 & $13 \pm 3.1$ & $30 \pm 1.9 *$ & $14 \pm 4.2$ & $244 \pm 87$ & $859 \pm 246^{*}$ & $281=153$ \\
\hline 0.30 & 8 & $12 \pm 3.3$ & $32 \pm 4.4^{*}$ & $11 \pm 3.2$ & $168 \pm 73$ & $724 \pm 251^{*}$ & $189 \pm 48$ \\
\hline 0.35 & 7 & $12 \pm 4.0$ & $34 \pm 6.9 *$ & $13 \pm 2.9$ & $205 \pm 141$ & $670 \pm 221 *$ & $271 \pm 172$ \\
\hline \multicolumn{8}{|c|}{ Halothanelnitrous oxide } \\
\hline 0.25 & 8 & $12 \pm 2.3$ & $29 \pm 3.3^{*}$ & $11 \pm 1.9$ & $228 \pm 100$ & $814 \pm 145^{*}$ & $232 \pm 105$ \\
\hline 0,30 & 8 & $11 \pm 1.4$ & $32 \pm 4.0^{*}$ & $11 \pm 1.1$ & $248 \pm 82$ & $1125 \pm 575^{*}$ & $208 \pm 86$ \\
\hline
\end{tabular}

PAP = pulmonary artery pressure, $P V R=$ pulmonary vascular resistance.

* Denotes significantly different from control ( $\mathrm{p}<0.05$ ).

tData presented from surviving arimals only.

the first 5 min of the air infusion. The pulmonary hypertension is indicative of an increase in resistance due to mechanical blockage, vasoconstriction ${ }^{19}$ or possibly an alteration in autonomic activity as reported ${ }^{20}$ with highdose nitrous oxide. Nitrous oxide has also been shown to have sympathetic effects ${ }^{21}$ and to inhibit norepinephrine removal by the lungs. ${ }^{22}$ All of these factors may also contribute to the rise in PVR

In recent years, much controversy has arisen over the best available anaesthetic technique for neurosurgery in the sitting position. Discussion has centred around the use of nitrous oxide because of its ability to expand bubbles and therefore aggravate the mechanical and physiological effects associated with VAE. It stands to reason that these effects might also influence the incidence of paradoxical air embolism where a patent foramen ovale exists. Consequently, the avoidance of nitrous oxide as an anaesthetic for patients in the sitting position has been suggested. Conversely, it has been suggested that the bubble expansion ability of nitrous oxide enables the clinician to detect small air bubbles earlier, although this practice is questionable, especially where very large VAE may lead to circulatory failure. ${ }^{23}$ Still others have advocated the use of $\mathrm{N}_{2} \mathrm{O}$ challenges to detect residual pulmonary vascular gas following VAE. ${ }^{24}$

The occurrence of arterial air embolism from venous origin is not fully established in man. Case reports ${ }^{9-11}$ have suggested that bubble passage through the pulmonary circulation can occur in the absence of an intracardiac defect, as we have also shown in animal studies, ${ }^{6}$ when the rate of venous air infusion exceeds the rate of excretion. In the present study, the incidence of spillover of venous bubbles was reduced at an air infusion rate of $0.30 \mathrm{ml} \cdot \mathrm{kg}^{-1} \cdot \mathrm{min}^{-1}$ when nitrous oxide was used with pentobarbitone anaesthesia as compared to halothane. This might be explained, partially at least, by the greater solubility of nitrous oxide causing expansion of the bubbles to such a degree that more effective trapping occurred in the pulmonary microcirculation.

Chang et al. ${ }^{25}$ concluded from an in vitro model study that with bubbles greater than 28 microns in diameter effective filtration should occur. For halothane to increase the likelihood of spillover of VAE, there might be an associated reduction in vascular tone or in the control of large A-V shunts within the lungs. Spillover of VAE through pulmonary shunts is likely ${ }^{26,27}$ although any direct action of halothane on these vessels is not reported. Extra-alveolas pulmonary shunts were reported in three. out of four dogs examined, ${ }^{28}$ ranging in size up to 240 microns diameter ${ }^{27}$ and although rarely in man, they have been reported as large as 500 microns. ${ }^{29}$ Niden and Aviado ${ }^{27}$ suggested that pulmonary shunts may be pressure responsive and open with elevated PAP or hypoxia, allowing venous glass beads to spillover into the pulmonary veins.

The results of this study do not allow us to delineate between increased protection from spillover of VAE into the arteries with pentobarbitone $/ \mathrm{N}_{2} \mathrm{O}$ versus a decrease in protection with halothane $/ \mathrm{N}_{2} \mathrm{O}$; although, a combination of these two factors is likely. Price et al ${ }^{30}$ reported an increase in physiological shunting in humans with halothane and halothane $/ \mathrm{N}_{2} \mathrm{O}$ but no significant change in PAP or PVR. Another explanation might involve a reduction in hypoxic pulmonary vasoconstriction with halothane $^{31}$ caused by arterial hypoxia, although this effect temains to be completely resolved.

Our data indicate that halothane anaesthesia did not significantly increase the incidence of spillover of VAE as compared to pentobarbitone; however, with the addition of nitrous oxide, the incidence was greater for halothane' $\mathrm{N}_{2} \mathrm{O}$ than pentobarbitone $/ \mathrm{N}_{2} \mathrm{O}$. The use of the halothane' $\mathrm{N}_{2} \mathrm{O}$ mixture also resulted in greater mortality in dogs subjected to venous air embolism. 


\section{Acknowledgements}

The authors wish to thank Ms. Sue Luehr for her technical assistance and Mrs. Sandra Starnader for preparing this manuscript.

\section{References}

I Chan KS, Yang WJ. Survey of literature related to the problems of gas embolism in the human body. J Biomech 1969; 2: 299-304.

2 Mehta M, Sokoll MD, Gergis SD. Effects of venous air embolism on the cardiovascular system and acid base balance in the presence and absence of nitrous oxide. Acta Anaesthesiol Scand 1984; 28: 226-31.

3 Ohkuda $K$, Nakahara $K$, Binder $A$, Staub $N C$. Venous air emboli in sheep: reversible increase in lung microvascular permeability. J Appl Physiol 1981: 51: 887-94.

4 Munson ES. Transfer of nitrous oxide into body cavities. Br J Anaesth 1974; 46: 202-9.

5 Butler $B D$, Hills $B A$. The lung as a filter for microbubbles. J Appl Physiol 1979; 47: 537-43.

6 Butler $B D$, Hills $B A$. Transpulmonary passage of venous air emboli. J Appl Physiol 1985; 59: 543-7.

7 Spencer MP, Oyana $Y$. Pulmonary capacity for dissipation of venous gas emboli. Aerosp Med 1971; 42: 822-7.

8 Katz J, Luehr S, Hills BA, Butler BD. Halothane decreases pulmonary filtration of venous air emboli. Anesthesiology 1985; 63: A523.

9 Marquez J, Sladen A, Gendell H, Boehnte M, Mendelow $H$. Paradoxical cerebral air embolism without an intracardiac septal defect. J Neurosurg 1981; 55: 997-1000

to Jacobsen WK, Briggs BA, Mason $L$. Paradoxical air embolism associated with a central total parenteral nutrition catheter. Crit Care Med 1983; 11:388-9.

II Harrison GR. Paradoxical air embolus. Anaesthesia 1986; 41: 763.

12 Hills $B A$, Grulke DC. Evaluation of ultrasonic bubble de tectors in vitro using calibrated microbubbles at selected velocities. Ultrasonics $1975 ; 13: 181-4$.

13 Holl EP Jr, Webb WR, Cook WA, Unal MO. Air embolism, hemodynamics and therapy. Ann Thorrac Surg 1966; 2: $551-60$.

14 Munson ES, Merrick HC. Effect of nitrous oxide on venous air embolism. Anesthesiology 1966; 27: 783-7.

15 Munson ES. Effect of nitrous oxide on the pulmonary circulation during venous air embolism. Anesth Analg 1971; 50: 785-92.

16 Perkins-Pearson NAK, Marshall WK, Bedford RF. Atrial pressures and the seated position. Implication for paradoxical air embolism. Anesthesiology 1982; 57: 493-7.

17 Durant TM, Long JM, Oppenheimer MJ. Pulmonary (venous) air embolism. Am Hean J 1947; 33: 269-81.

18 Michel L, Poskantzer DL, McKusick KA, Nardi GL, Malt $R A$. Fatal paradoxical air embolism to the brain: com- plication of central venous catheterization. J Parenteral and Enteral Nutrition 1982; 6: 68-70.

19 Josephson S. Pulmonary air embolization in the dog. II. Evidence and location of pulmonary vasoconstriction. Scand I Clin Lab Invest 1970; 26: 113-23.

20 Steffey EP, Johnson BH, Eger EI. Nitrous oxide intensifies the pulmonary arterial pressure response to venous injection of carbon dioxide in the dog. Anesthesiology 1980; 52: 52-5.

21 Fukunaga AF, Epstein RM. Sympathetic excitation during nitrous oxide-halothane anesthesia in the cat. Anesthesiology 1973; 39: 23-6.

22 Naito $H$, Gillis $C N$. Effects of halothane and nitrous oxide on removal of norepinephrine from the pulmonary circulation. Anesthesiology 1973; 39: 575-80.

23 Shapiro $H M$. Neurosurgical anesthesia and intracranial hypertension. In: Miller RD (Ed). Anesthesia. 2nd ed. New York: Churchill Livingstone, 1986: 1563-620.

24 Shapiro HM. Yoachim J, Marshall LF. Nitrous oxide challenge for detection of residual intravascular pulmonary gas following venous air embolism. Anesth Analg 1982; 61: 304-6.

25 Chang HK, Weber ME, Thomson J, Marrin RR. Hydrodynamic features of pulmonary air cmbolism: a model study. J Appl Physiol 1981; 51; 1002-8.

26 Verstappen FTV, Bernards $J A$, Kreuzer $F$. Effeets of pulmonary gas embolism on circulation and respiration in the dog. Ill. Excretion of venous gas bubbles by the lungs. Pficugers Arch 1977; 370:67-70.

27 Niden AH. Aviado DM. Effect of pulmonary embolism on the pulmonary circulation with special references to arteriovenous shunts in the lungs. Circ Res 1956, 4: 67-73.

28 Rahn $H$, Stroud $C$, Tobin $C E$. Visualization of arteriovenous shunts by cinefluorography in the lungs of normal dogs. Proc Soc Exp Bio Med 1952; 80: 239-41.

29 Tobin $C E$, Zariquiey $M O$. Atteriovenous shunts in the human lung. Proc Soc Exp Bio Med 1950; 75: 827-9.

30 Price $H L$, Cooperman $L H$, Warden JC el al. Pulmonary hemodynamics during general anesthesia in man. Anesthesiology 1969; 30: 629-36.

31 Marshall $C$, Lindgren L, Marsizall BE. Effects of halothane, enflurane and isoflurane on hypoxic pulmonary vasoconstriction in rat lungs in vitro. Anesthesiology 1984 ; 60: $304-8$. 


\section{Résumé}

On a étudié, chez les chiens, les effets qu'avait le protoxyde d'azote $\left(\mathrm{N}_{2} \mathrm{O}\right)$, utilisé lors d'une anesthésie ci l'halothane ou au pentobarbita!, sur la fittration d'embolie gazeuse (EGV) par la circulation pulmonaire. On a causé des embolies gazeuses veineuses dans l'oreillette allant de 0.25 à $0.35 \mathrm{ml} \cdot \mathrm{kg}^{-1} \cdot \mathrm{min}^{-1}$ pendant 30 minutes, chez des chiens anesthésiess au pentobarbital, au pentobarbitall $\mathrm{N}_{2} \mathrm{O}$, à l'halothane, ou à l'halothane $/ \mathrm{N}_{2} \mathrm{O}$. Les animaux étaient en position de Trendelenburg en décubitus dorsal. Une sonde ulirason Doppler, locatisée au-dessus de I'aarte suprarénale, détectair les bultes d'air artérieltes qui échappaient d la filtration pulmonaire. On a décelé aucune bulles d' air a $0.25 \mathrm{ml} \cdot \mathrm{kg}^{-1} \cdot \mathrm{min}^{-1}$, mais à $0.30 \mathrm{ml} \cdot \mathrm{kg}^{-1} \cdot \mathrm{min}^{-1}$ l'incidence était de 11 pour cent (pensobarbital), 0 pour cent (pentobarbitall $\mathrm{N}_{2} \mathrm{O}$ ), 33 pour cent (halothaned, et 63 pour cent (halothane $\mathrm{N}_{2} \mathrm{O}$ ) et à $0.35 \mathrm{~mL} \cdot \mathrm{kg}^{-1} \cdot \mathrm{min}^{-1}$, elle était 44 pour cent (pentobarbital), 14 pour cent (pentobarbital/ $\mathrm{N}_{2} \mathrm{O}$ ), et de 56 pour cent (halothane). La moitié des chiens recevant des EGV avec de l' halothane $\mathrm{N}_{2} \mathrm{O}$ क $0.30 \mathrm{ml} \cdot \mathrm{kg}^{-1}$ sont morts dans les dix minutes après l' infusion de l' air. Nous n'avons donc pas érudié d'animaux à la dose élevée qui suivait $\left(0.35 \mathrm{ml} \cdot \mathrm{kg}^{-1}\right)$. Les résultats laissent entendre qu'il est possible que la conséquence hémodynamique soit plus importante et que la passibilité d'écoulement de bulles d"air veineuses dans les artères soit augmentée dans l'apparition de EGV avec protoxyde d' azote, si ce dernier est utilisé avec une anesthésie à l'halorhane en comparaison d̀ une anesthésie au pentobarbital. 